\title{
Calcification of the intervertebral disc and ossification of posterior longitudinal ligament in children
}

\author{
Jun-Jie Du*, Yu-Fei Chen", Ye Peng, Xiao-jie Li and Wei Ma
}

\begin{abstract}
Background: IDC in children, first reported by Baron in 1924, is very rare. OPLL of the cervical spine mainly affect people ages 50-70 years. The coexistence of IDC and OPLL in children is very rare, only six cases with 3 to 24 months' follow-up were reported to date.

Case presentation: A 6-year-old boy presented with complains of neck pain at July 2007. The boy was treated by conservative treatment and observed up for 9 years. Neck pain greatly improved after a one-month conservative treatment and never recur. Laboratory tests revealed elevated ESR and CRP at admission and found nothing abnormal at 19-month and 9-year follow-up. Computed tomography and magnetic resonance imaging revealed IDC at C2/3, C3/4 and OPLL at C3/4 at admission and found minor calcification at C2/3 remained but calcification at C3/4 and OPLL at C3/4 completely disappeared at 19-month and 9-year follow-up. Nineteen months after initial diagnosis, restoration of T2-weighted signal intensity of C2/3 and C3/4 discs was observed through MRI. Loss of T2-weighted signal intensity of C2/3 disc and decrease of T2-weighted signal intensity of C3/4 disc was observed at 9-year follow-up.
\end{abstract}

Conclusions: IDC with OPLL in children is very rare. Conservative treatments are recommended with affirmative short-term and long-term clinical effects. More intensive observation with long-term follow-ups may be needed to warrant the clinical effects.

Keywords: Intervertebral disc calcification, Ossification of the posterior longitudinal ligament, Pediatric, Cervical spine

\section{Background}

Calcification of intervertebral disc in children is rare. Since firstly reported by Baron in 1924, approximately 400 cases were reported [1]. Although traumatic, infectious, inflammatory, and nutritional mechanisms were thought to contribute to calcification of intervertebral disc in children, the detailed etiology remain not defined. Ossification of the posterior longitudinal ligament (OPLL) mainly affect people ages $50-70$ years, also with unclear etiology. Calcification of intervertebral disc in children is usually thought to be self-limiting with favorable prognosis, while OPLL in adults usually aggravates gradually and needs surgery when present with myelopathy or radiculopathy. The

\footnotetext{
* Correspondence: dujunjie205@hotmail.com; chenyufei_2012@hotmail.com Department of Orthopaedics, Air Force General Hospital of PLA, 30 Fucheng Road, Beijing 100142, People's Republic of China
}

coexistence of calcification of intervertebral disc and OPLL is very rare, only six cases with 3 to 24 months' follow-up were reported to date [2-6]. We reported the first two cases of cervical intervertebral disc calcification combined with OPLL in children in 2012 [3] and followed one case for more than nine years. The purpose of this case report is to describe the 9-year follow-up result. To our knowledge, long-term follow-up for cervical intervertebral disc calcification combined with OPLL is firstly reported here.

\section{Case presentation}

A 6-year-old boy presented with right-sided neck pain for 6 months was admitted in our institution on July 2007 , with no history of recent trauma, fever or infection. The pain localized in the right side of neck, without radiating pain. The pain exacerbated for several days and

(c) The Author(s). 2018 Open Access This article is distributed under the terms of the Creative Commons Attribution 4.0 International License (http://creativecommons.org/licenses/by/4.0/), which permits unrestricted use, distribution, and reproduction in any medium, provided you give appropriate credit to the original author(s) and the source, provide a link to the Creative Commons license, and indicate if changes were made. The Creative Commons Public Domain Dedication waiver (http://creativecommons.org/publicdomain/zero/1.0/) applies to the data made available in this article, unless otherwise stated. 
not alleviated by using analgesics. Visual Analogue Scale (VAS) for cervical pain was 7.0. Physical examination revealed no palpable masses or torticollis. Neurological examination revealed nothing abnormal. Laboratory tests revealed normal white blood cell count $\left(6170 / \mathrm{mm}^{3}\right.$, normal range: $\left.5000-12,000 / \mathrm{mm}^{3}\right)$ and elevated ESR $(69 \mathrm{~mm} / \mathrm{h}$, normal range: 0 to $20 \mathrm{~mm} / \mathrm{h})$ and CRP $(11.80 \mathrm{mg} / \mathrm{L}$, normal range: 0 to $5 \mathrm{mg} / \mathrm{L}$ ). Radiograph and CT showed calcification of intervertebral disc at $\mathrm{C} 2 / 3$ and $\mathrm{C} 3 / 4$ levels, accompanied by C3/4 level OPLL (Fig. 1a, c and d). MRI revealed decreased signal intensity of $\mathrm{C} 2-4$ discs and $\mathrm{C} 3 / 4$ posterior longitudinal ligament on T2-weighted images, with slight dura compression (Fig. 1b). The patient was treated with analgesics for 2 weeks, interrupted cervical traction for 2 weeks and cervical collar for 1 month. After a one-month conservative treatment, the patient's symptoms greatly improved. VAS for cervical pain decreased to 1.0.

Nineteen months later, in March 2009, the boy complained no discomfort. Laboratory tests (including white
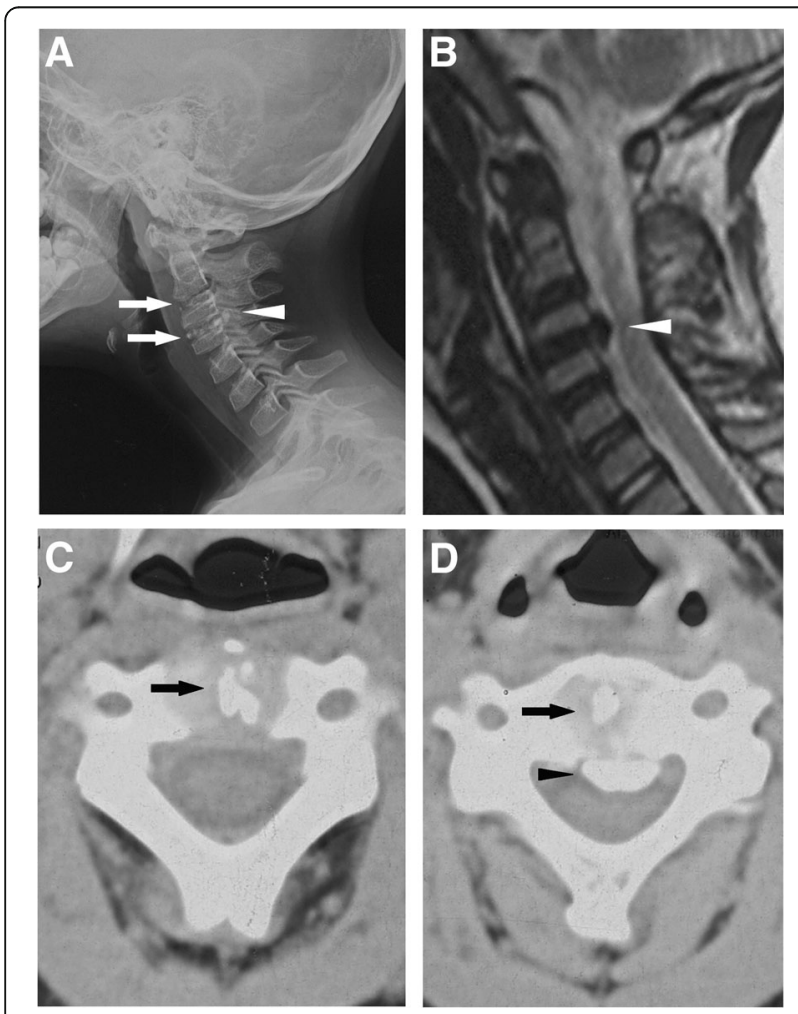

Fig. 1 Radiological imaging at admission. a Lateral cervical spine radiograph showed C2/3and C3/4 IDC (thin arrows) and OPLL at C3 and C4 (thick arrow). b Magnetic resonance imaging showed that spinal cord was compressed anteriorly at the C3/4 level (arrow). c Axial computed tomography through C2/3 revealed IDC (thick arrows) at C2/3. d Axial computed tomography through C3/4 revealed IDC (thick arrows) at C3/4 and OPLL at C3/4 level (thin arrow). (Adopted and reedited from Du et al. [3] with permissions of all authors) blood cell count, ESR and CRP) revealed nothing abnormal. C3/4 intervertebral disc calcification and OPLL had disappeared, only minor calcification at $\mathrm{C} 2 / 3$ intervertebral disc left (Fig. 2a, c and d). MRI demonstrated restoration of T2-weighted signal intensity of $\mathrm{C} 2 / 3$ and $\mathrm{C} 3 / 4$ discs (Fig. 2b).

When last seen in October 2016, there was still no discomfort. Laboratory tests revealed nothing abnormal. No sign of C3/4 intervertebral disc calcification and OPLL was observed (Fig. 3a, c and d). Minor calcification at C2/ 3 intervertebral disc remained (Fig. 3a, c and d). MRI demonstrated loss of T2-weighted signal intensity of $\mathrm{C} 2 / 3$ disc and decrease of T2-weighted signal intensity of $\mathrm{C} 3 / 4$ disc (Fig. 3b). Narrowing of C2/3 intervertebral space, flatting of $\mathrm{C} 3$ body, widening of posterior edge of $\mathrm{C} 3 / 4$ disc were observed in CT scan (Fig. 3c and d).

\section{Discussion and conclusions}

The incidence of intervertebral disc calcification (IDC) in children is low, with only approximately 400 cases
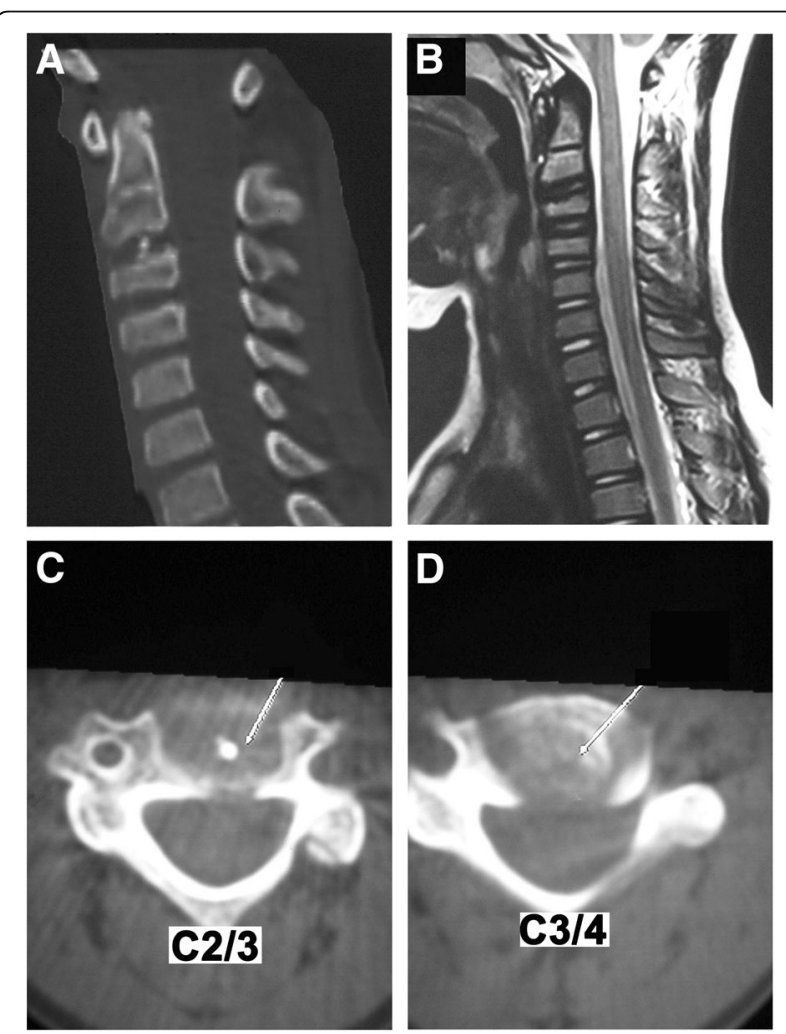

Fig. 2 Radiological imaging at 19-month follow-up. a Computed tomography revealed the IDC and OPLL at the C $3 / 4$ level has disappeared, only minor calcification at C2/3 intervertebral disc left. b Magnetic resonance imaging revealed restoration of T2-weighted signal intensity of $\mathrm{C} 2 / 3$ and $\mathrm{C} 3 / 4$ discs. c Axial computed

tomography through $C 2 / 3$ revealed minor calcification at $C 2 / 3$ intervertebral disc left. d Axial computed tomography through C3/4 revealed IDC and OPLL at the C3/4 level disappeared. (Adopted and reedited from Du et al. [3] with permissions of all authors) 

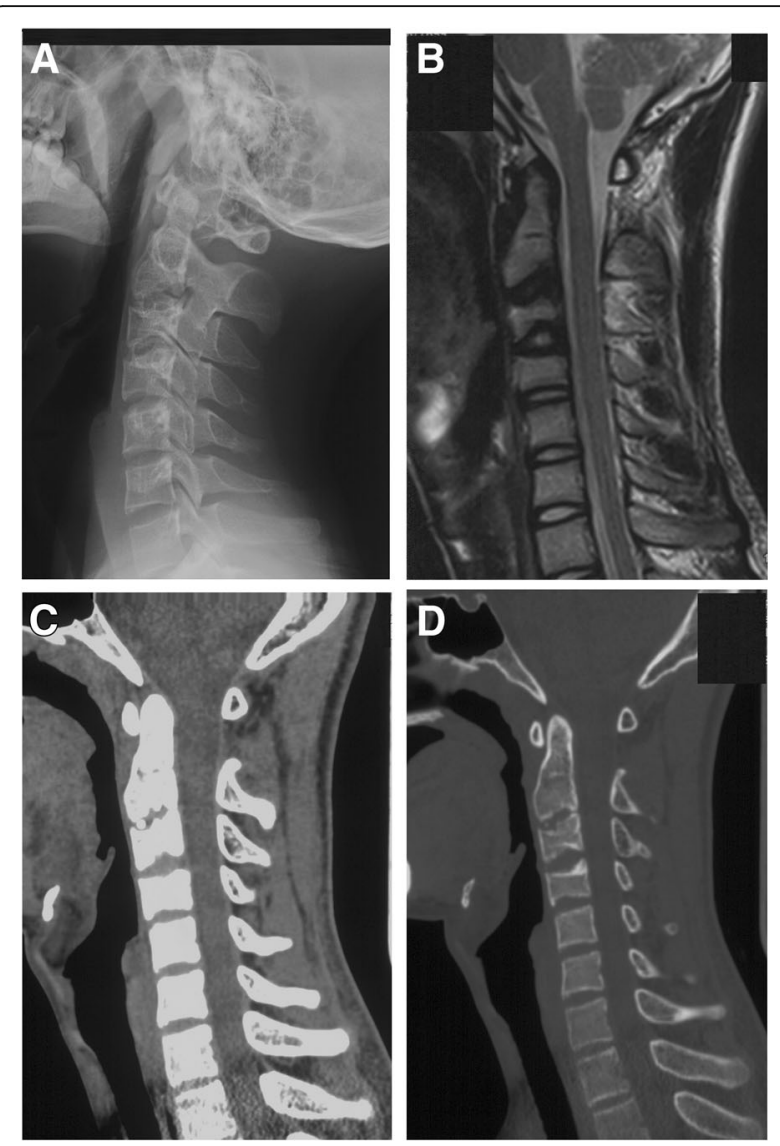

Fig. 3 Radiological imaging at 9-year follow-up. a Lateral cervical spine radiograph showed minor IDC remained at C2/3. b Magnetic resonance imaging revealed loss of T2-weighted signal intensity of C2/3 disc and decrease of T2-weighted signal intensity of C3/4 disc. c and $\mathbf{d}$ Computed tomography revealed minor calcification at C2/3 intervertebral disc left, IDC and OPLL at the C3/4 level disappeared. Narrowing of C2/3 intervertebral space, flatting of C 3 body, widening of posterior edge of C3/4 disc were observed

reported since 1924. Intervertebral disc calcifications in children were divided in symptomatic and asymptomatic groups by Beluffi [7], who believed the number of asymptomatic patients could be larger than symptomatic patients. Blomquist et al. [8] reported 15 cases of IDC in children, of which 11 were symptomatic. Given that calcification of disc in children may be only an incidental finding without symptoms [9-12], the exact incidence may be underestimated [13, 14]. IDC mainly affect 5-to 12-year-old children [15], although newborn infant involvement was reported [7]. Males are more susceptible to IDC than females, with male-to-female ratio 13:6 [15, 16]. IDC mostly occurs in lower cervical spine and upper thoracic spine [17], with the most common level at C6/7 [18, 19]. First reported in 1838, OPLL has been widely reported since the 1960s [20]. OPLL usually affect people ages $50-70$, the average onset age is 51.2 years in men and 48.9 years in women [21], with male-to-female ratio roughly 2:1 [22].OPLL is relatively more common in East Asian populations than Caucasian. The prevalence of OPLL was reported to be $1.5 \%$ to $3.7 \%$ in Japan and 0.1-1.7\%in Europe and United States [21, 23-25]. The most commonly involved levels are C4-6 [26]. IDC with OPLL in children is an extremely rare situation, only six cases reported to date (Table 1) [2-6]. We reported the first two cases of cervical IDC with OPLL in children in 2012, while Fu et al. [2] reported the first thoracic case. Given that most reported cases occurred in East Asia, like OPLL in adult, IDC with OPLL in children may also have racial susceptibility.

The etiology of IDC in children is still unclear. Trauma, infection, nutritional supply, vitamin D disorder, hereditary deficit may contribute to IDC in children $[9,13,27-$ 29]. Elevated ESR was reported to be the most sensitive indicator [15]. Coordinate with previous reports, elevated ESR and CRP are observed in our case, which suggested that infection may play a role in etiology of IDC in children. OPLL in adults is also considered to be multifactorial. Trauma [21], inflammation [30], genetics [31], environment [23], diet [32], glucose intolerance [33], obesity [33] and hypoparathyroidism [34] may contribute to the onset and progress of OPLL in adults. Trauma was seen in 2 cases of 6 reported cases of IDC with OPLL in children (incidence: $33.33 \%)$. Elevated inflammation indicators were seen in 3 cases (incidence: 50\%, with one case didn't give out inflammation indicators [6]). These results suggested that trauma and inflammation may play a role in the etiology of IDC with OPLL in children.

The most common clinical symptom of IDC in children is neck pain, affecting $80-90 \%$ cases [35]. Torticollis occurred in $40 \%$ of cases [11]. Other symptoms and signs include: perivertebral muscle spasms, low-grade fever, radicular pain, tenderness, and dysphagia (in anterior herniation cases). Only 5\% patients of OPLL in adults were free of symptoms, 95\% patients had clinical symptoms [21]. Different from IDC in children, varying degrees radiculopathy and myelopathy can be present in OPLL in adults [22], including balance dysfunction, muscular weakness, stagger, radicular pain, numbness and dysdiadochokinesia. Neck pain or back pain was seen in all the 6 reported cases of IDC with OPLL in children (incidence: $100 \%$ ), neurological deficit (radicular pain), cervical stiffness, and torticollis was present in 1 case (incidence: $16.67 \%)$, respectively.

Conservative treatment, including analgesics, NSAIDS, muscle relaxants, cervical collar, traction and limited physical activity, is the mainstay treatment for IDC in children. Vast majority of children with IDC can be cure by conservative treatment. $66.7 \%$ patients got a complete relief of symptoms within 3 weeks and 95\% patients would complete relieve within 6 months [19]. Recurrence of symptoms rarely occurs 
Table 1 Reported cases of IDC combined with OPLL in children

\begin{tabular}{|c|c|c|c|c|c|c|c|}
\hline Author & $\begin{array}{l}\text { Reported } \\
\text { year }\end{array}$ & Age/sex & Location & $\begin{array}{l}\text { Pre-existing } \\
\text { trauma }\end{array}$ & $\begin{array}{l}\text { Clinical } \\
\text { presentation }\end{array}$ & $\begin{array}{l}\text { WBC }\left(/ \mathrm{mm}^{3}\right) / C R P(\mathrm{mg} / \mathrm{L}) / \\
\operatorname{ESR}(\mathrm{mm} / \mathrm{h})\end{array}$ & $\begin{array}{l}\text { Radiographic changes/ } \\
\text { follow-up }\end{array}$ \\
\hline Du et al. [3] & 2012 & $8 / F$ & $\begin{array}{l}\text { IDC at } C 6 / 7 \\
\text { OPLL at } C 6 / 7\end{array}$ & Yes & NP\& ND & $5860 / 16.5 / 55$ & $\begin{array}{l}\text { IDC\& OPLL disappeared/ } \\
2 \text { years }\end{array}$ \\
\hline Fu et al. [2] & 2011 & $11 / M$ & $\begin{array}{l}\text { IDC at T6/7,T7/8 } \\
\text { OPLL atT6/7, T7 }\end{array}$ & No & $\mathrm{BP}$ & Normal & $\begin{array}{l}\text { IDC aggravated, OPLL } \\
\text { alleviated/3 months }\end{array}$ \\
\hline Wang et al. [4] & 2016 & $11 / F$ & $\begin{array}{l}\text { IDC at } C 5 / 6 \\
\text { OPLL at } C 5 / 6, C 6\end{array}$ & No & NP & Normal & $\begin{array}{l}\text { Mild IDC remained, OPLL } \\
\text { disappeared/6 months }\end{array}$ \\
\hline Mizukawa et al [5] & 2017 & $6 / F$ & $\begin{array}{l}\text { IDC at } C 4 / 5 \\
\text { OPLL at C } 4 / 5\end{array}$ & No & NP & $8600 / 15 /-$ & $\begin{array}{l}\text { IDC\& OPLL disappeared/ } \\
6 \text { months }\end{array}$ \\
\hline O'Dell et al [6] & 2016 & $9 / M$ & $\begin{array}{l}\text { IDC at } C 2 / 3 \\
\text { OPLL at } C 2 / 3\end{array}$ & Yes & $\begin{array}{l}\text { NP \& stiffness } \\
\text { torticollis; }\end{array}$ & - & $\begin{array}{l}\text { IDC disappeared, mild OPLL } \\
\text { remained/2 years }\end{array}$ \\
\hline Current case & 2012 & $6 / M$ & $\begin{array}{l}\text { IDC at } C 2 / 3, C 3 / 4 \\
\text { OPLL atC3/4 }\end{array}$ & No & NP & 6170/11.8/69 & $\begin{array}{l}\text { Mild IDC remained, OPLL } \\
\text { disappeared, } 19 \text { years }\end{array}$ \\
\hline
\end{tabular}

- not mentioned

$I D C$ intervertebral disc calcification, OPLL ossification of posterior longitudinal ligament, WBC white blood cells, CRP C-reactive protein, ESR erythrocyte

sedimentation rate, NP neck pain, ND neurological deficit, $B P$ back pain

[36], but Hoffman [37] reported a child with IDC who suffered from neck pain and neurological deficit requiring surgery 6 years after initial diagnosis. Cases of IDC with symptom relapse 1 year after the initial onset were also reported [36]. Surgical treatment is controversial in cases with neurological deficit. Some authors suggested that conservative therapy could produce satisfactory results even when neurological deficit was present $[9,10]$. Conservative treatment was proven effective even for the patient with neurological impairment due to large posterior protrusion [10]. Different from IDC with OPLL in children, surgery is more common for patients with OPLL in adults because of the progressive nature and poor prognosis [38]. Due to the extremely stenosis of cervical canal of the OPLL patients in adult, spinal cord injury (SCI) can occur even with minor trauma. Concerning that conservative treatments were adopted for all the 6 reported cases of IDC with OPLL in children with good effect, we suggest conservative treatment should be the first choice for these patients. Surgery should only be under consideration for cases with rapid progressive neurologic deterioration and high risk of paraplegia.

Coordinate with previous reports [16, 39-42], narrowing of the involved intervertebral space, flatting and wedging of adjacent vertebral body were observed in the current case at 9-year follow-up. IDC with OPLL in children seemed benign and self-limiting. Only mild IDC of $\mathrm{C} 2 / 3$ remained but IDC of C3/4 and OPLL at C3/4 totally disappeared in the current case at 9-year follow-up. For all the 6 reported cases of IDC with OPLL in children, IDC disappeared in 3 cases (50\%), aggravated in 1 case $(16.67 \%)$, relieved but remained in 2 cases (33.33\%). OPLL disappeared in 4 cases (66.67\%), relieved but remained in 2 cases (33.33\%). The only aggravated IDC case was treated by a 2-week lumbar belt immobilization [2]. Aggravation of IDC but relief of OPLL result in a reduction in spinal canal stenosis for the patient at 3-month follow-up, which made the conservative treatment still a promising choice. Given that this only reported aggravated IDC case was in thoracic disc, we can infer that thoracic IDC in children may have a different nature history with cervical IDC in children.

Through the 9-year follow-up, the changes of T2-weighted signal intensity for the involved discs drew our attention. Dehydration of intervertebral discs, which led to hypointense of T2-weighted signal intensity in MRI, was considered as a typical imaging manifestation of disc degeneration [43-45]. Restorations of T2-weighted signal intensity in MRI of degenerated discs were reported in several researches after dynamic stabilization systems implantation for low back pain patients, which were considered as decelerations of the degeneration process and regenerations of degenerated discs [46-49]. Nineteen months after initial diagnosis, restoration of T2-weighted signal intensity of $\mathrm{C} 2 / 3$ and $\mathrm{C} 3 / 4$ discs was observed in the current case through MRI. Similar change was reported by Liu [16], who reported a calcified disc restored to normal T2-weighted signal intensity at 2-year follow-up for a 10-year-old girl. The mechanisms of "rehydration" of the calcified discs are still unclear. Given that the spontaneous "rehydration" phenomenon is only seen in children but seldom adults, we can infer that this might be attribute to differences between discs of children and adults. The biggest differences between discs in children and in adults are the presence of microvascular blood supply for cartilage endplate and annulus fibrosus, as well as notochord cells, in children. Intervertebral discs appear vascularized more well in children than in adults [50]. Blood vessels penetrate into the anulus in infants but disappear by late childhood apart from some small capillaries [50-52]. The capillaries penetrate in the subchondral plate of intervertebral discs by regularly spaced nutrient canals in fetus and infants but disappear in childhood $[52,53]$. The thickness of cartilaginous endplates of intervertebral discs diminishes with age [52, 54]. The notochordal cells exist in the intervertebral discs of 
fetus and infants but disappear by 10 years of age in humans, just as the time morphological signs of degeneration can be seen [55]. So, we speculated that these may contribute to the spontaneous "rehydration" phenomenon. Interestingly, similar "rehydration" phenomenon is seen in adult low back pain patients after dynamic stabilization systems implantation [46-49]. We can infer that the change of load distribution may also play a role in the "rehydration" phenomenon.

IDC with OPLL in children is very rare. Conservative treatments are recommended with affirmative short-term and long-term clinical effects. But given that such cases were so rare and radiographic changes in more than $30 \%$ cases didn't improve, more intensive observation with long-term follow-ups may be needed to warrant the clinical effects.

\section{Abbreviations \\ CRP: C-reactive protein; CT: Computed tomography; ESR: Erythrocyte sedimentation rate; IDC: Intervertebral disc calcification; MRI: Magnetic resonance imaging; OPLL: Ossification of the posterior longitudinal ligament; WBC: White blood cells}

\section{Acknowledgements}

We would like to thank Guan-Nan Luan for her technical support on Literature searching.

\section{Funding}

This study was supported by Chinese National Natural Science Foundation Project (No. 81501929) and Beijing Municipal Science \& Technology Commission (No. Z161100000116057).

\section{Availability of data and materials}

All the data supporting our findings is contained within the manuscript.

\section{Authors' contributions}

All the authors were involved in conducting, drafting or revising the manuscript. All the authors approved the final version of the manuscript for submission. Study conception and supervision: J-JD and Y-FC; Clinical management of the case: J-JD; Analysis and interpretation of data: Y-FC, YP and WM; Review of literatures: J-JD, Y-FC and YP, edition of images: X-JL and WM. Case Follow-Up: Y-FC, X-JL and WM.

\section{Ethics approval and consent to participate}

The institutional Ethics Review Board of Air Force General Hospital of PLA approved the study.

\section{Consent for publication}

We obtained written informed consent for the publication of this case by the boy and his custodians.

\section{Competing interests}

The authors declare that they have no competing interests.

\section{Publisher's Note}

Springer Nature remains neutral with regard to jurisdictional claims in published maps and institutional affiliations.

Received: 9 November 2017 Accepted: 9 August 2018

Published online: 05 September 2018

\section{References}

1. Lam SK, Niedzwecki CM, Daniels B, Mayer RR, Vakharia MM, Jea A. Acute spinal cord injury associated with multilevel pediatric idiopathic intervertebral disc calcification: case report. J Neurosurg Pediatr. 2016;17(2):182-6.
2. Fu Z, Shi J, Jia L Jr, Yuan W Jr, Guan Z. Intervertebral thoracic disc calcification associated with ossification of posterior longitudinal ligament in an eleven-year-old child. Spine (Phila Pa 1976). 2011;36(12):E808-10.

3. Du JJ, Meng H, Cao YJ, Li FQ, Luo ZJ. Calcification of the intervertebral disc and posterior longitudinal ligament in children. J Spinal Disord Tech. 2012; 25(1):59-63.

4. Wang G, Kang Y, Chen F, Wang B. Cervical intervertebral disc calcification combined with ossification of posterior longitudinal ligament in an-11-year old girl: case report and review of literature. Childs Nerv Syst. 2016;32(2):381-6.

5. Mizukawa K, Kobayashi T, Yamada N, Hirota T. Intervertebral disc calcification with ossification of the posterior longitudinal ligament. Pediatr Int. 2017:59(5):622-4.

6. O’Dell MC, Flores M, Murray JV Jr. Pediatric idiopathic intervertebral disc calcification. Pediatr Neurol. 2016:61:115-6.

7. Beluffi G, Fiori P, Sileo C. Intervertebral disc calcifications in children. Radiol Med. 2009:114(2):331-41

8. Blomquist HK, Lindqvist M, Mattsson S. Calcification of intervertebral discs in childhood. Pediatr Radiol. 1979;8(1):23-6.

9. Dai LY, Ye H, Qian QR. The natural history of cervical disc calcification in children. J Bone Joint Surg Am. 2004;86-A(7):1467-72.

10. Bajard X, Renault F, Benharrats T, Mary P, Madi F, Vialle R. Intervertebral disc calcification with neurological symptoms in children: report of conservative treatment in two cases. Childs Nerv Syst. 2010;26(7):973-8.

11. Yang HS, Chen DY, Yuan W, Yang LL, Tsai N, Lin QS. Paresis associated with aconuresis caused by intervertebral disc calcification at C7-t1: a case report and review of the literature. Spine (Phila Pa 1976). 2010;35(10):E434-9.

12. El Demellawy D, Robison JG, Pollack IF, Green MD, Alper CM, Reyes-Mugica M. Idiopathic intervertebral disc calcification in childhood: an atypical case of an uncommon entity for pediatric pathologists. Pediatr Dev Pathol. 2013;16(6):432-7.

13. Lernout C, Haas H, Rubio A, Griffet J. Pediatric intervertebral disk calcification in childhood: three case reports and review of literature. Childs Nerv Syst. 2009:25(8):1019-23.

14. Ho C, Chang S, Fulkerson D, Smith J. Children presenting with calcified disc herniation: a self-limiting process. J Radiol Case Rep. 2012;6(10):11-9.

15. Tsutsumi S, Yasumoto Y, Ito M. Idiopathic intervertebral disk calcification in childhood: a case report and review of literature. Childs Nerv Syst. 2011. 27(7):1045-51

16. Liu W, Tang C, Liu L, Zhu QS, Huang LF. Cervical intervertebral disC calcification with extreme lateral herniation in a child: T2-weighted signal intensity of the involved disc can be restored to normal. Childs Nerv Syst. 2016;32(4):749-52

17. Swischuk LE, Jubang M, Jadhav SP. Calcific discitis in children: vertebral body involvement (possible insight into etiology). Emerg Radiol. 2008; 15(6):427-30.

18. Rutges J, Creemers LB, Dhert W, Milz S, Sakai D, Mochida J, Alini M, Grad S. Variations in gene and protein expression in human nucleus pulposus in comparison with annulus fibrosus and cartilage cells: potential associations with aging and degeneration. Osteoarthr Cartil. 2010;18(3):416-23.

19. Sonnabend DH, Taylor TK, Chapman GK. Intervertebral disc calcification syndromes in children. J Bone Joint Surg Br. 1982;64(1):25-31.

20. Fargen KM, Cox JB, Hoh DJ. Does ossification of the posterior longitudinal ligament progress after laminoplasty? Radiographic and clinical evidence of ossification of the posterior longitudinal ligament lesion growth and the risk factors for late neurologic deterioration. J Neurosurg Spine. 2012;17(6):512-24.

21. Matsunaga S, Sakou T. Ossification of the posterior longitudinal ligament of the cervical spine: etiology and natural history. Spine (Phila Pa 1976). 2012; 37(5):E309-14.

22. Abiola R, Rubery P, Mesfin A. Ossification of the posterior longitudinal ligament: etiology, diagnosis, and outcomes of nonoperative and operative management. Global Spine J. 2016;6(2):195-204.

23. Stapleton CJ, Pham MH, Attenello FJ, Hsieh PC. Ossification of the posterior longitudinal ligament: genetics and pathophysiology. Neurosurg Focus. 2011;30(3):E6.

24. Iwasaki M, Okuda S, Miyauchi A, Sakaura H, Mukai Y, Yonenobu K, Yoshikawa $\mathrm{H}$. Surgical strategy for cervical myelopathy due to ossification of the posterior longitudinal ligament: part 2: advantages of anterior decompression and fusion over laminoplasty. Spine (Phila Pa 1976). 2007; 32(6):654-60. 
25. Sasaki E, Ono A, Yokoyama T, Wada K, Tanaka T, Kumagai G, Iwasaki H, Takahashi I, Umeda T, Nakaji S, et al. Prevalence and symptom of ossification of posterior longitudinal ligaments in the Japanese general population. J Orthop Sci. 2014;19(3):405-11.

26. Sohn S, Chung CK, Yun TJ, Sohn CH. Epidemiological survey of ossification of the posterior longitudinal ligament in an adult Korean population: threedimensional computed tomographic observation of 3,240 cases. Calcif Tissue Int. 2014;94(6):613-20.

27. Kusabiraki S, Tsubata S. Two karate kids with pediatric idiopathic intervertebral disc calcification. Spine J. 2014;14(12):3048.

28. Kim HR, Ha DH, Lee SM, Kim SH, Wenokor C. Acute symptomatic intervertebral disk calcification in a child with retropharyngeal edema: computed tomography and magnetic resonance findings. J Clin Rheumatol. 2011;17(7):365-7.

29. Chu J, Wang T, Pei S, Yin Z. Surgical treatment for idiopathic intervertebral disc calcification in a child: case report and review of the literature. Childs Nerv Syst. 2015:31(1):123-7.

30. Kawaguchi Y, Nakano M, Yasuda T, Seki S, Suzuki K, Yahara Y, Makino H, Kitajima I, Kimura T. Serum biomarkers in patients with ossification of the posterior longitudinal ligament (OPLL): inflammation in OPLL. PLoS One. 2017;12(5):e0174881.

31. Ikegawa S. Genetics of ossification of the posterior longitudinal ligament of the spine: a mini review. J Bone Metab. 2014;21(2):127-32.

32. Okamoto K, Kobashi G, Washio M, Sasaki S, Yokoyama T, Miyake Y, Sakamoto N, Ohta K, Inaba Y, Tanaka H, et al. Dietary habits and risk of ossification of the posterior longitudinal ligaments of the spine (OPLL); findings from a case-control study in Japan. J Bone Miner Metab. 2004; 22(6):612-7.

33. Akune T, Ogata N, Seichi A, Ohnishi I, Nakamura K, Kawaguchi H. Insulin secretory response is positively associated with the extent of ossification of the posterior longitudinal ligament of the spine. J Bone Joint Surg Am. 2001;83-A(10):1537-44

34. Ono K, Yonenobu K, Miyamoto S, Okada K. Pathology of ossification of the posterior longitudinal ligament and ligamentum flavum. Clin Orthop Relat Res. 1999;359:18-26.

35. Mahapatra SK, Sud A, Mehtani A. Pediatric cervical disc calcification simulating tubercular spondylitis - a case report. J Clin Orthop Trauma. 2013:4(1):46-8.

36. Sasagawa T, Hashimoto F, Nakamura T, Maruhasi Y, Matsumoto N, Segawa T, Yamamoto D, Goshima K, Murakami H, Tsuchiya H. A pediatric case of single-level idiopathic cervical intervertebral disk calcification with symptom relapse 1 year after initial onset. J Pediatr Orthop. 2014;34(3):282-6.

37. Hoffman Al, Lambiase RE, Levine SM. Intervertebral cervical disk calcification requiring operative management in a child. AJR Am J Roentgenol. 1998; 171(3):898-9.

38. Pham MH, Attenello FJ, Lucas J, He S, Stapleton CJ, Hsieh PC. Conservative management of ossification of the posterior longitudinal ligament. A review. Neurosurg Focus. 2011;30(3):E2.

39. Wong CC, Pereira B, Pho RW. Cervical disc calcification in children. A longterm review. Spine (Phila Pa 1976). 1992;17(2):139-44.

40. Sieron D, Gruszczynska K, Machnikowska-Sokolowska M, Olczak Z, Knap D Baron J. Intervertebral disc calcification in children: case description and review of relevant literature. Pol J Radiol. 2013;78(1):78-80.

41. Bagatur AE, Zorer $G$, Centel T. Natural history of paediatric intervertebral disc calcification. Arch Orthop Trauma Surg. 2001;121(10):601-3.

42. Spapens N, Wouters C, Moens P. Thoracolumbar intervertebral disc calcifications in an 8-year-old boy: case report and review of the literature. Eur J Pediatr. 2010;169(5):577-80

43. Urban JP, Roberts S. Degeneration of the intervertebral disc. Arthritis Res Ther. 2003;5(3):120-30.

44. Hadjipavlou AG, Tzermiadianos MN, Bogduk N, Zindrick MR. The pathophysiology of disc degeneration: a critical review. J Bone Joint Surg Br. 2008;90(10):1261-70

45. Pfirrmann CW, Metzdorf A, Zanetti M, Hodler J, Boos N. Magnetic resonance classification of lumbar intervertebral disc degeneration. Spine (Phila Pa 1976). 2001;26(17):1873-8.

46. Yilmaz A, Senturk S, Sasani M, Oktenoglu T, Yaman O, Yildirim H, Suzer T, Ozer AF. Disc rehydration after dynamic stabilization: a report of 59 cases. Asian Spine J. 2017;11(3):348-55.

47. Fay LY, Wu JC, Tsai TY, Tu TH, Wu CL, Huang WC, Cheng H. Intervertebral disc rehydration after lumbar dynamic stabilization: magnetic resonance image evaluation with a mean followup of four years. Adv Orthop. 2013; 2013:437570.

48. Cho BY, Murovic J, Park KW, Park J. Lumbar disc rehydration postimplantation of a posterior dynamic stabilization system. J Neurosurg Spine. 2010;13(5):576-80.

49. Luo L, Zhang C, Zhou Q, Zhao C, Wang L, Liang L, Tu B, Ouyang B, Gan Y. Effectiveness of transpedicular dynamic stabilization in treating discogenic low back pain. World Neurosurg. 2018;111:e192-e8.

50. Rudert M, Tillmann B. Detection of lymph and blood vessels in the human intervertebral disc by histochemical and immunohistochemical methods. Ann Anat. 1993;175(3):237-42.

51. Hassler $\mathrm{O}$. The human intervertebral disc. A micro-angiographical study on its vascular supply at various ages. Acta Orthop Scand. 1969;40(6):765-72.

52. Urban JP, Smith S, Fairbank JC. Nutrition of the intervertebral disc. Spine (Phila Pa 1976). 2004:29(23):2700-9.

53. Whalen $\mathrm{J}$, Parke WW, Mazur JM, Stauffer ES. The intrinsic vasculature of developing vertebral end plates and its nutritive significance to the intervertebral discs. J Pediatr Orthop. 1985:5(4):403-10.

54. Bernick S, Cailliet R. Vertebral end-plate changes with aging of human vertebrae. Spine (Phila Pa 1976). 1982;7(2):97-102.

55. Aguiar DJ, Johnson SL, Oegema TR. Notochordal cells interact with nucleus pulposus cells: regulation of proteoglycan synthesis. Exp Cell Res. 1999; 246(1):129-37

\section{Ready to submit your research? Choose BMC and benefit from:}

- fast, convenient online submission

- thorough peer review by experienced researchers in your field

- rapid publication on acceptance

- support for research data, including large and complex data types

- gold Open Access which fosters wider collaboration and increased citations

- maximum visibility for your research: over $100 \mathrm{M}$ website views per year

At BMC, research is always in progress.

Learn more biomedcentral.com/submissions 